\title{
Influence of Customer Relationship Management, Brand Equity, Perceived Product Quality, Perceived Price on Customer Value and Purchase Intention (Studies Philips Light Bulb in Batam)
}

\author{
Lukmanul Hakim ${ }^{1}$, Nanis Susanti ${ }^{2} \&$ Ujianto $^{2}$ \\ ${ }^{1}$ Program Management Studies, University of Riau Kepulauan, Riau Islands, Indonesia \\ ${ }^{2}$ Program Management Studies, University of 17 Agustus 1945, Surabaya, Indonesia \\ Correspondence: Priyono, Graduate Master of Management Program of Universitas Bina Darma, Palembang, \\ Indonesia, Indonesia. Tel: 62-812-1697-4878. E-mail: priyono.unu_sidoarjo@yahoo.com
}

Received: April 24, 2017

Accepted: May 31, 2017

Online Published: June 15, 2017

doi:10.5539/ijef.v9n7p122

URL: https://doi.org/10.5539/ijef.v9n7p122

\begin{abstract}
This study tried to determine and analyze the deeper understanding of the influence of customer relationship management, brand equity, perceived of product quality, perceived value and price to the customer at the customer's purchase intention Philips light bulb in Batam.

The population in this study are all users (consumers) electric light bulb philips brands in the city of Batam. Testing of the model in this study, with Generalized Least Square Estimation (GLS), analysis of structural equation modeling (SEM), proportional random sampling method and software assistance Amos 22, on 240 respondents from eight times the 30 indicators the study variables. The test results indicate the model (fit) seen from the GFI, AGFI, TLI, CFI, RMSEA and CMIN / DF, each of 0915, 0901, 0949, 0953, 0063, and 1,376 are all that are in the range of expected values so that the model can be accepted.

The results showed that: 1). Customer relationship management influence on customer value, it shows that with good customer relationship management program, will increase customer value. 2) Customer relationship management influence on purchase intention, it shows that with good customer relationship management program, will increase customer value. 3) Brand equity effect on customer value, it shows that with a good brand equity, will increase customer value. 4). Brand equity effect on purchase intention, it shows that with a good brand equity, will increase customer value. 5) Perceived quality of product effect on customer value, it indicates that the perceived quality of a good product, will increase customer value. 6). Perceived quality of product effect on purchase intention, this suggests that the perceived quality of a good product, will increase purchase intention. 7). Perceived price effect on customer value, it indicates that the perceived price friendly, will increase customer value. 8) Perceived price effect on purchase intention, this suggests that the perceived price friendly, will increase purchase intention. 9). Customer value effect on purchase intention, it shows that with high customer value, will raise the purchase intention.
\end{abstract}

Keywords: customer relationship management, brand equity, perceived of product quality, perceived price, purchase intention

\section{Introduction}

Philips lights currently face a very tough competition, this is because the various brands of light bulbs from China offer cheaper prices, so Philips as a principal trying to do strategy with the intention to increase selling power to the Distributor in Batam. The strategy used is to provide discounts for consumers and distribute Philips light bulb products throughout Batam area. With this strategy is expected to face the competition of Chinese light bulbs that seem increasingly vigorous, which this can affect the sales of Philips light bulb, especially in Batam.

Tjiptono (2015, p. 54) mentions that product quality has a close relationship with purchase intention, where the quality of the product provides a boost to the consumer to establish strong ties with the company. In the long run of these companies to understand the expectations of its customers and their needs. Kotler and Armstrong (2012, p. 28) say that marketing is the process by which companies create value for customer and build strong relationship with customers in order to capture value from customers in return. Kalakota and Robinson (2001) state that 
Customer Relationship Management (CRM) is an integration of coordinated sales, marketing and service strategies. Kotler and Keller (2009, p. 342) explain that brand equity is a set of brand assets and liabilities related to a brand, its name and its symbol, which adds or subtracts the value provided by a good or service to the company or customer. Irawan, Pane (2011, p. 66) mentions that Purchase intention is a strong desire passionate tendency very high heart to get something by way of sacrifice, get something by paying some money. Parasuraman et al. (1997). In the discussion of his research, the desired level of service (desired desire) and adequate service level (adequate service). Desired desire is the level of expectation that consumers expect to receive.

Tjahyadi Studies (2012) states that customer value has a close relationship with Purchase intention. Consumers who receive a higher value level have stronger Purchase intention to recommend it to others. The interactions between service employees and customers are considered to be the most important contributor to customers' assessment of quality (Besterfield, Dale, 1995; Tansic, 1993). (The interaction between employees in the service and consumer sectors greatly contributes to the consumer's assessment of the quality of services it receives). Brady and Cronin (2002), hypothesized that the perception of employee behavior directly influences the quality of service interaction. Brady and Cronin (2002) further states that there is a positive relationship between employee perception and interpersonal service quality perception.

The study of consumer response is very important for the company. Mithas, Krishnan, and Fornell (2005) said that customer response is essential to the long-term success of a firm. The same thing also conveyed by Gropper and Boily (1999), that promote patient (customer) satisfaction as the ultimate goal for the success of the organization (Customer response as the main goal for organizational success). Sheth and Parvatiyar (2011, p. 119), stated that CRM stores customer information and records all contacts that occur between customers and companies, and creates customer profiles for company staff who need information about the customer. Buttle (2007), Customer Relationship Marketing (CRM) is a core business that integrates internal processes and functions as well as external networks to create and deliver value for targeted customers in order to make a profit. CRM supported high-quality customer data and facilitated information technology.

\subsection{Conceptual Framework}

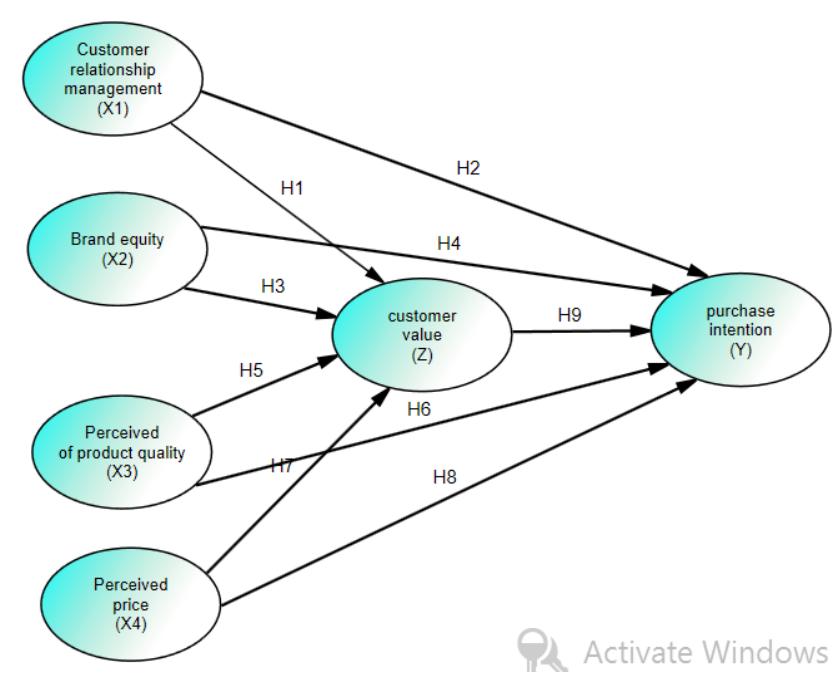

Figure 1. Conceptual framework

\section{Research Methodology}

In this study used survey sample from a population using questionnaires as a means of collecting data and conduct analysis of respondents as research objects. The design for this type of research that tests the hypothesis includes the theory and the basic truth of the hypothesis being tested.

\subsection{Population and Sample}

In this study, the estimation used is Generalized Least Square Equation Estimates (GLS), and the number of samples studied for 240 respondents, which came from 8 times 30 indicators of variables in this study. The provisions are in accordance with the provisions that use the reference (Hair et al., 2010, Ferdinand, 2012, p. 85) 


\subsection{Data Analysis Techniques}

The data analysis in this research uses analytical method which can give simultaneous analysis process related to multi variant research model like in this research that is Structural Equation Modeling (SEM) analysis with Amos Version 22, Ferdinand (2012, p. 6).

\subsection{Test Validity and Reliability}

\subsubsection{Validity Test}

A test or instrument measuring instrument can be said to have high validity if the tool performs its measuring function or provides a measuring result that is appropriate to the purpose of the measurement. A valid measuring instrument is not only able to disclose data accurately and provide a careful picture of the data.

\subsubsection{Test Reliability}

Singarimbun (2014, p. 124), the validity indicates the extent to which a gauge measures what it wants to measure. Azwar (2013, p. 5), a test instrument or measuring instrument may be said to have a high degree of validity if the device performs its measuring function, or provides a measuring result appropriate to the purpose of the measurement. Tests that produce data that are irrelevant to the purpose of measurement are said to be tests that have low validity. So the data validity test aims to determine whether the measuring tool in the questionnaire used is correct. The measurement is done by calculating the correlation between each statement with the total score and using Structural Equation Modeling (SEM).

\section{Result and Discussion}

\subsection{Test Validity}

Validity shows how accurately an instrument measures a particular concept to be measured. In other words, the validity questioned whether the instrument used to measure an antity, really measures the intended attributes, so that the instrument can be known to be useful or not.

Validity also means the extent to which a measuring instrument measures what it wants to measure (Singarimbun \& Effendi, 2014, p. 73). How to measure the validity can use internal consistency (internal conssistency) is by Pearson product moment correlation method. If the correlation between each question with the total score shows significant results (significance $<0.05$ and correlation $>0.4$ ), then the question item is valid which means it has the validity of the construct.

\subsection{Pearson Correlation Test Validity Test Result}

Validity test results show significant for all indicators or question items, which means that the indicators or question items for each of the variables contained in the questionnaire have met the validity requirements. From the result of Pearson product moment correlation, it is known that all question items in the questionnaire have a significant correlation at the error rate of $5 \%(* *<0.05)$, so it can be said that all question items are valid and can be processed further.

\subsection{Reliability Test}

Reliability is the ability of an instrument to show stability and consistency in measuring concepts. This means: firstly when measuring an object multiple times with the same instrument, it should have the same result; Second, reliability also means the score of respondents obtained is actually the actual score of the respondent in terms of characteristics or traits measured: third, reliability is also defined as how many measurement errors in measurement instruments. Reliability is a measure of the internal consistency of the indicators of a construct showing the degree to which each indicator indicates a common latent construct (Ferdinand, 2012, p. 60). The recommended approach in assessing a measurement model is to assess the amount of composite reliability and variance extracted from each construct. The limit value used to assess an acceptable level of reliability is $\geq 0.70$ for composite reliability. The second measure of reliability is the extracted variance, which shows the amount of variance of the indicators developed. The high value of variance extracted indicates that the indicators have been well represented in the latent constructs developed (Ferdinand, 2012, p. 61). Recommended value at a level of at least 0.50

Reliability measurement can also use the cronbach alpha $(\alpha)$ coefficient which shows how well the question items are positively related to other question items. If the cronbach alpha coefficient of 0.6 or more, then the research data is considered good enough or reliable to be used as input from data analysis (Hair et al., 2010; Maholtra, 2008, p. 55). Hair et al. (2010) also states that the corrected total correlation item is at least 0.3 so that the question items can be used in subsequent data processing. 
The results of reliability test with cronbach alpha test $(\alpha)$ in this study indicate that all research variables are reliable, because all the coefficient alpha value of each research variable is larger than standardized (0.6), so that each question item on Measurement instruments can be used. The value of corrected total correlation items of all question items is greater than 0.3.

\subsection{Normality Test Data}

Normal distribution of data is evaluated through skewness and kurtosis values, variables with skewness or kurtosis coefficients with a critical ratio of over \pm 2.58 indicating abnormal distribution, and otherwise normal (Ferdinand, 2012). From the test known all manifest variables that amounted to 71 items of questions have a critical ratio below \pm 2.58 , so otherwise normal.

\subsection{Measurment Research Model}

Measurement model is a modeling process in research directed to investigate the undimensionality of indicators that explain a factor or a latent variable (Ferdinand, 2012, p. 70).

This research data is processed by using AMOS 22, before studying the measurement model of each variable in this research, will be analyzed first dimensions of the indicators that make up each variable.

Based on the nature of the number, which is getting closer to the zero value is smaller then in this study the amount of regression that exist between the dimensions with the indicator, or between the variable of the indicator (loading factor) with the constructed variable is translated as follows:

$\leq 0.40$ : The relationship is weak

0.41 - 0.55: Moderate relationship

0.56 - 0.69: Strong relationship

$\geq 0.70$ : The relationship is very strong.

\subsection{Research Model Structure}

The model structure is used to describe research causality models with tiered relationships. The initial model of the research (Proposed Model) that has been made, analyzed by structural equation model with the help of AMOS 22 software. The results of the analysis of the initial model (independence model) can be seen in Figure 2.

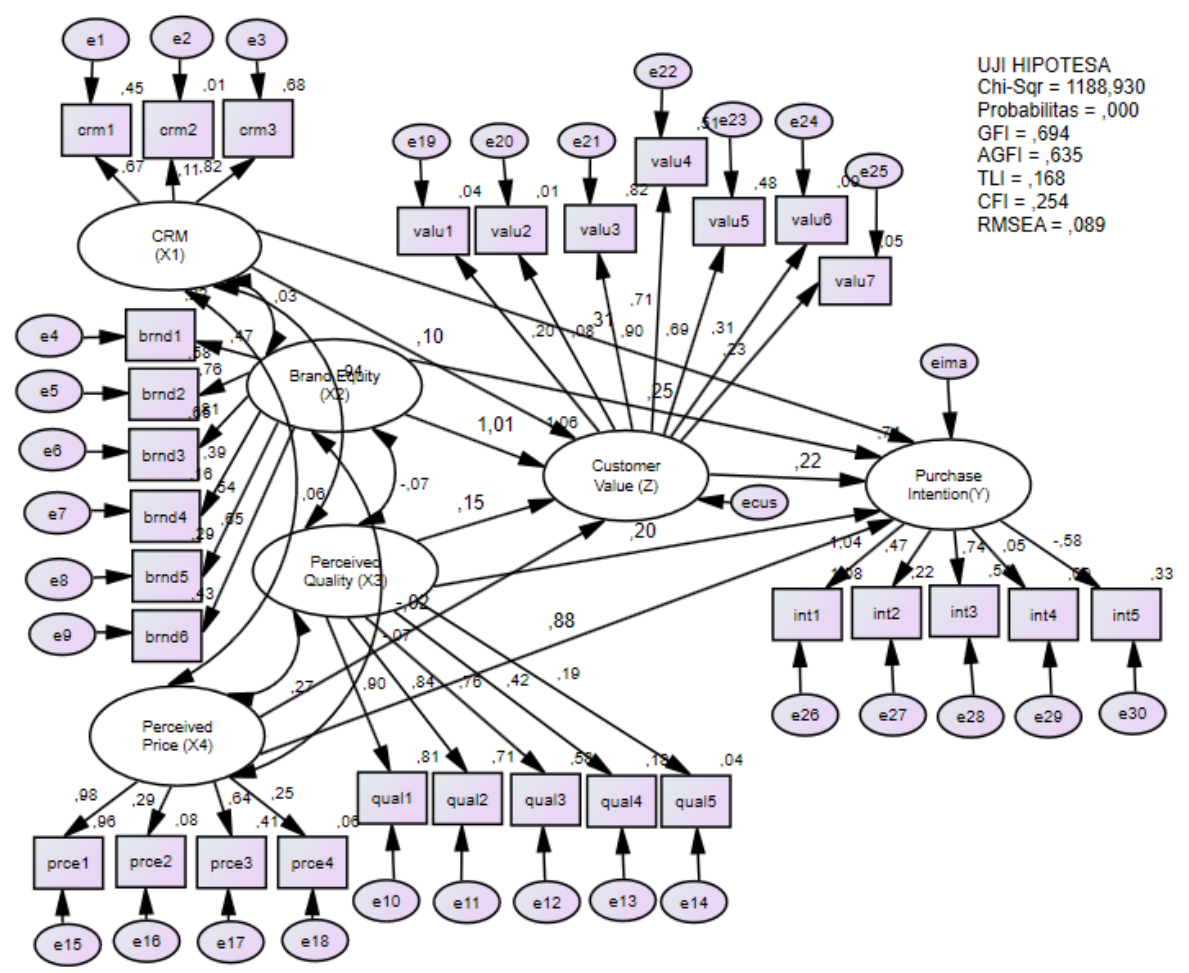

Figure 2. Structural early research model (proposed model)

Source: The results of processed researchers. 
Table 1. Goodness of fit index test results structrual proposed model

\begin{tabular}{ccccc}
\hline No & Goodness of Fit Index & Cut-off Value & Model Test Results & information. \\
\hline 1 & $\chi^{2} /$ Chi-Square & & 1188,930 & Must be small \\
2 & Significance probability & $\geq 0,05$ & 0,000 & Less \\
3 & GFI & $\geq 0,90$ & 0,694 & Less \\
4 & AGFI & $\geq 0,90$ & 0,635 & Less \\
5 & TLI & $\geq 0,95$ & 0,168 & Less \\
6 & CFI & $\geq 0,94$ & 0,254 & Less \\
7 & RMSEA & $\leq 0,08$ & 0,089 & Less \\
8 & Relative $\chi 2(\mathrm{CMIN} / \mathrm{DF})$ & $\leq 2,00$ & 3,049 & Less \\
\hline
\end{tabular}

Source: Prepared researcher with Amos.

From a goodness of fit judgment, the probability is equal to zero (chi square is large) so that the null hypothesis can not be rejected, or accept the null hypothesis that the sample covariant and the population covariance are not the same. Besides, there are some other goodness of fit criteria that have not fulfilled such as TLI, GFI, AGFI and RMSEA value is only close to the desired range. But from the evaluation of regression weightnya, all variables have a causality relationship and have a critical ratio value is not equal to zero. This indicates that the accepted research model has not yet entered the specified (standard) criteria.

Therefore, in this research, there is no modification of the model, but the index modification as shown in Estimated Parameter Proposed Model, in the attachment. Based on very rigorous and careful theoretical considerations, modifications of the index to the model remain under the guidance that this index modification will not significantly alter the result of causality (parameter). Compared to the estimation of the proposed model parameters, and the final model parameter estimation results can be seen that there is no significant change before and after the analysis so that the modification is acceptable (Hair et al., 2008).

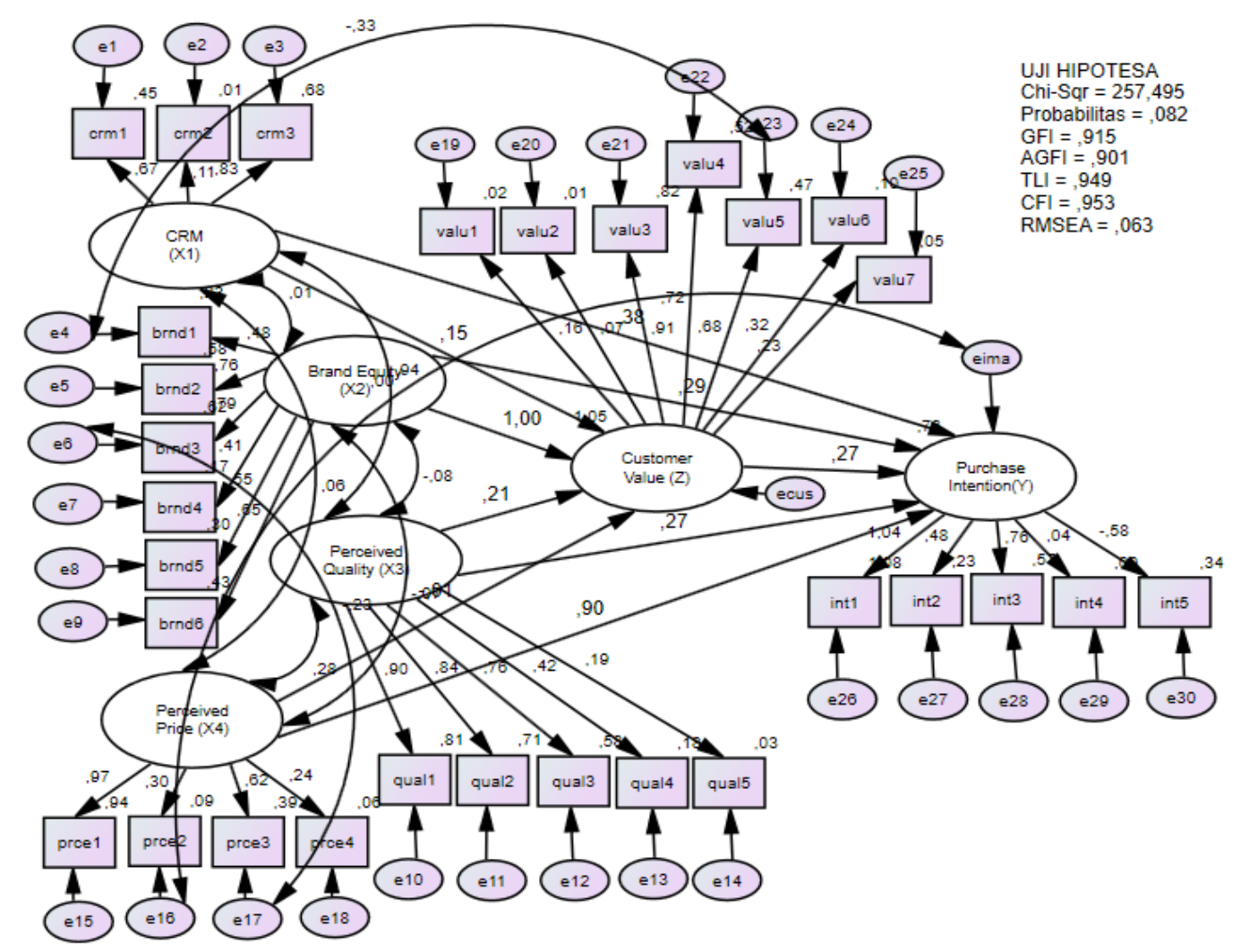

Figure 3. Structural research model (final model)

Source: The results of the processed researchers with Amos. 


\subsection{Test of Conformity Model (Goodness of Fit Test)}

This test is done to see if the model developed fit (fit) with the available data. The items used for this test are shown in Table 2.

Results of data processing using a sample of 240 indicates the level of significance to test the above difference hypothesis is 257.495 with probability 0.082 . This shows that there is no difference between the sample covariance matrix and the population covariance matrix, so the null hypothesis is accepted (accepted if probability $\geq 0.05$ ).

Meanwhile, the values of GFI, AGFI, TLI, CFI, RMSEA and CMIN / DF were 0.915, 0.901, 0.949, 0.953, 0.063 and 1.376 respectively in the expected range of values so that the model was acceptable (Table 2).

Table 2. Test result of goodness of fit index structural final model

\begin{tabular}{clccc}
\hline No & Goodness of Fit Index & Cut-off Value & Model Test Results & information. \\
\hline 1 & $\chi 2$ / Chi-Square & & 257,495 & good \\
2 & Significance probability & $\geq 0,05$ & 0,082 & good \\
3 & GFI & $\geq 0,90$ & 0,915 & good \\
4 & AGFI & $\geq 0,90$ & 0,901 & good \\
5 & TLI & $\geq 0,95$ & 0,949 & good \\
6 & CFI & $\geq 0,95$ & 0,953 & good \\
7 & RMSEA & $\leq 0,08$ & 0,063 & good \\
8 & Relative $\chi 2(\mathrm{CMIN} / \mathrm{DF})$ & $\leq 2,00$ & 1,376 & good \\
\hline
\end{tabular}

Source: Prepared researcher.

\subsection{Parameter Testing}

To determine the causality relationship between each variable, tested to the null hypothesis that the regression coefficient between the relation with zero through $t$ test in the regression model. Taking into account the regression results in Table 3 it is known that the critical ratio (CR) value which is identical with the $t$ test in the regression analysis shows that all the regression coefficients are not significantly equal to zero, thus causality relation in the model is acceptable.

Table 3 shows that the amount of regression between Perceived Of Product Quality (Prc_Qua) variable and Customer Value (cust_value) is 0,205 and CR $=3,311$, meaning Perceived Of Product Quality variable has significant effect on Customer Value.

The amount of regression between variable Perceived Price (Per_Price) with Customer Value (cust_value) equal to $-0,009$ and value of $C R=-0,076$, meaning Perceived Price variable influence not signifikan to Customer Value.

The amount of regression between variable Perceived Price (Per_Price) with Customer Value (cust_value) equal to $-0,009$ and value of $\mathrm{CR}=-0,076$, meaning Perceived Price variable influence not signifikan to Customer Value.

The amount of regression between variable of Customer Relationship Management (CRM) with Customer Value (cust_value) equal to 0,154 and value of $\mathrm{CR}=-3,461$, it means Customer Relationship Management variable have strong and significant influence to Customer Value.

The amount of regression between Brand Equity (Brd_Equi) with Customer Value (cust_value) 1,000 and CR = 4,535 , it means that Brand Equity variable has strong and significant effect on Customer Value.

The amount of regression between Customer Value variable (cust_value) with Purchase Intention (Pur_Inten) variable equal to 0,273 and value of $\mathrm{CR}=7,377$, it means Customer Value variable have significant effect to Purchase Intention.

The amount of regression between variable Perceived Price (Per_Price) with Purchase Intention (Pur_Inten) variable equal to 0,898 and value of $\mathrm{CR}=6,897$, meaning Perceived Price variable have strong and significant influence to Purchase Intention. 
Table 3. Estimation of final parameter model

\begin{tabular}{lcccc}
\hline Relationship Structure & Path Coefficient & The value of C.R. & Probability (P value) & Information Sig. $\leq \mathbf{0 , 0 5}$ \\
\hline cust_value $\leftarrow$ CRM & 0,154 & 3,461 & 0,000 & Significant \\
Pur_Inten $\leftarrow$ CRM & 0,376 & 5,610 & 0,000 & Significant \\
cust_value $\leftarrow$ Brd_Equi & 1,000 & 4,535 & 0,000 & Significant \\
Pur_Inten $\leftarrow$ Brd_Equi & 0,289 & 5,556 & 0,000 & Significant \\
cust_value $\leftarrow$ Prc_Qua & 0,205 & 3,311 & 0,000 & Significant \\
Pur_Inten $\leftarrow$ Prc_Qua & 0,270 & 5,425 & 0,000 & Significant \\
cust_value $\leftarrow$ Per_Price & $-0,009$ & $-0,076$ & 0,439 & Not Significant \\
Pur_Inten $\leftarrow$ Per_Price & 0,898 & 6,899 & 0,000 & Significant \\
Pur_Inten $\leftarrow$ cust_value & 0,273 & 7,377 & 0,000 & Significant \\
\hline
\end{tabular}

Source: Prepared researcher.

\subsection{Coefficient of Determination Analysis $\left(R^{2}\right)$}

Analysis of the influence between latent variables is done to test how much contribution influence between latent variables formed or percentage of variance between variables can be explained as seen in Table 5 .

Table 4. Coefficient of determination $\left(\mathrm{R}^{2}\right)$

\begin{tabular}{ccc}
\hline Latent Variables & $\begin{array}{c}\text { Square Multiple } \\
\text { Correlation }\left(\mathbf{R}^{2}\right)\end{array}$ & Information \\
\hline Customer Value (Z) & 0,853 & The influence of X1, X2, X3, and X4 together against Z is $85.3 \%$ \\
Purchase Intention (Y) & 0,758 & Contribution of influence X1, X2, X3, and X4 together to Y equal to 75,8\%. \\
\hline
\end{tabular}

Source: Results of the processed researchers.

Table 4 shows the following:

A. $85.3 \%$ variance on Customer Value variable can be explained by variable factor of Customer Relationship Management, Brand Equity, Perceived Of Product Quality, and Perceived Price.

B. 75.8\% variance in variable Purchase Intention can be explained by variable factor of Customer Relationship Management, Brand Equity, Perceived Of Product Quality, and Perceived Price.

\section{Hypothesis Test}

Customer relationship management has a significant effect on customer value.

There is influence of Customer Relationship Management to customer value of 0.154 , with the value of $\mathrm{CR}=$ 3.461. This means that customer relationship management that has been done by Philips light bulb company in Batam Island Riau Islands, will increase customer value by $15,4 \%$. This means that hypothesis 1 is accepted.

\section{Hypothesis 2}

Customer relationship management significantly affects purchase intention.

There is influence from Customer Relationship Management to purchase intention of 0.376 with $\mathrm{CR}=5,610$. This means that customer relationship management company Philips light bulb in Batam Island Riau Islands, will be able to increase purchase intention by $37,6 \%$. This means that hypothesis 2 is accepted.

\section{Hypothesis 3}

Brand equity has significant effect on customer value. Table 4, shows that there is influence of Brand equity to Customer Value of 1,000 with value $\mathrm{CR}=4,535$. This means that the brand equity of Philips light bulb in Batam Island Riau Islands, will be able to increase Customer Value by 100\%. This means that hypothesis 3 is accepted.

\section{Hypothesis 4}

Brand equity has significant effect on purchase intention. There is influence of Philips bulb brand equity to purchase intention in Batam Island Riau Islands equal to 0,289 with value of $\mathrm{CR}=5,556$. This means that Philips Light Equity Brand in Batam Island Riau Islands, will be able to increase purchase intention by $28.9 \%$. This means that hypothesis 4 is accepted.

\section{Hypothesis 5}

Perceived of product quality has a significant effect on customer value. There is influence of Perceived of product 
quality to customer value of 0.205 with value of $C R=3,311$. This means that in this study, Perceived of product quality which is precisely consumer of Philips light bulb can increase customer value in Batam Island Riau Islands equal to $20,5 \%$. This means that hypothesis 5 is accepted.

\section{Hypothesis 6}

Perceived of product quality has significant effect on purchase intention. There is influence of Perceived of product quality of Philips light bulb to purchase intention of consumer in Batam Island Riau Islands 0,270, with CR value 5,425. This means that Perceived of product quality of Philips light bulb has significant effect to consumer purchase intention in Batam Island Riau Islands. This means that hypothesis 6 is accepted.

\section{Hypothesis 7}

Perceived price has a significant effect on customer value. There is influence of Perceived price of Philips light bulb to customer value in Batam Island Riau Islands equal to -0.009 with value of $C R=-0,076$. This means that Perceived price by consumers have negative and insignificant effect on customer value. This means that hypothesis 7 is rejected.

\section{Hypothesis 8}

Perceived price has significant effect on purchase intention. There is influence from Perceived price of consumer to purchase intention of consumer in Batam Island of Riau Islands 0,898, with CR value 6,899. This means that Perceived price has a strong and significant influence to consumer purchase intention in Batam Island City in Batam Island Riau. This means that hypothesis 8 is accepted.

\section{Hypothesis 9}

Customer value significantly affects purchase intention. There is influence from Customer value to consumer purchase intention of Philips light bulb in Batam Island Riau Islands 0,273 with CR value $=7,377$. This means that customer value significantly affects the Purchase Intention of 27.3\%. This means that hypothesis 9 is accepted.

From the results of the analysis that has been done, then the details of hypothesis test results in this research are shown in Table 5.

Table 5. Research hypothesis test results

\begin{tabular}{llc}
\hline HYPOTHESES & \multicolumn{1}{c}{ STATEMENT } & RESULTS \\
\hline First & Customer relationship management has a significant effect on customer value & Be accepted \\
Second & Customer relationship management significantly affects purchase intention. & Be accepted \\
Third & Brand equity has significant effect on customer value & Be accepted \\
Fourth & Brand equity has significant effect on purchase intention & Be accepted \\
Fifth & Perceived of product quality has a significant effect on customer value & Be accepted \\
Sixth & Perceived of product quality has significant effect on purchase intention & Be accepted \\
Seventh & Perceived price has a significant effect on customer value & rejected \\
Eighth & Perceived price has significant effect on purchase intention. & Be accepted \\
Ninth & Customer value significantly affects purchase intention & Be accepted \\
\hline
\end{tabular}

Source: The results of processed researchers (2017).

\section{Conclusions and Recommendation}

\subsection{Conclusions}

The results of this study can be an alternative model or way of managing customer relationship management, brand equity, perceived of product quality, perceived price to customer value and purchase intention customer Philips lightbulb in Batam City.

1). Customer relationship management has a significant effect on customer value

The coefficient of customer relationship management line variables to customer value of Philips light bulb customers in Batam City is 0, 154 with critical ratio value (CR) 3,461 and probability value is 0.000 . The probability value is less than 0.05 , this indicates the effect of customer relationship management variables on customer value of Philips light bulb customers in Batam City is significant or reliable. While the positive value of beta to explain the effect is unidirectional, meaning that customer relationship management conducted Philips light bulb provider in Batam City in general contributed to increasing the value of Philips lightbulb customers in 
Batam City, and vice versa failure in implementing customer relationship management can reduce customer value In front of customer Philips bulb customers in Batam City. Donations given in the contribution amounted to 0.154 or $15.4 \%$.

\section{2). Customer relationship management significant effect on customer value}

The coef fi cient of the customer relationship management variable path to the customer value of Philips lightbulb customers in Batam City is 0,154 with the critical ratio value (CR) 3.461 and the probability value of 0.000 . The probability value is less than 0.05 , this indicates the effect of customer relationship management variables on customer value of Philips light bulb customers in Batam City is significant or reliable. While the positive value of beta to explain the effect is unidirectional, meaning that customer relationship management conducted Philips light bulb provider in Batam City in general contributed to increasing the value of Philips lightbulb customers in Batam City, and vice versa failure in implementing customer relationship management can reduce customer value In front of customer Philips bulb customers in Batam City. Donations given in the contribution amounted to 0.154 or $15.4 \%$.

\section{3). Customer relationship management significant effect on purchase intention}

The coef fi cient of customer relationship management variable path to purchase intention of Philips light bulb in Batam City is 0,376 with critical ratio value (CR) 5,610 and probability value equal to 0.000 . The probability value is less than 0.05 , this indicates the effect of customer relationship management variable on customer buying intention of Philips bulb in Batam City is significant or reliable. While the positive value beta explains the effect is unidirectional, meaning that the success of the philip light bulb provider in Batam City runs a good relationship with Philips light bulb customers contributes to the increasing attitude of buyers intention of Philips light bulb, likewise the failure in forming customer relationship management can lower the intention Buy Philips light bulb customers in Batam City. The contribution given in the contribution is 0.376 or $37.6 \%$.

4). Brand equity has significant effect on customer value

The Philips brand equity variable path coefficient of Philips light bulb value in Batam City is 1,000 with critical ratio value (CR) 4,535 and probability value is 0.000 . The probability value is less than 0.05 , this indicates the effect of Philips' light bulb brand equity variable on the value of Philips light bulb customers in Batam City is significant or reliable. While the positive value beta explains the effect is unidirectional, meaning the Philips brand light bulb contributes to the increase in customer value in Batam City, and vice versa failure in forming Philips light bulbs brand can decrease the value of Philips light bulb customers in Batam City. Donations in the contribution amounted to 1.00 or $100 \%$. This $100 \%$ value indicates that any increase in brand equity will be followed by a rise in customer value by a rise in brand equity.

\section{5). Brand equity has significant effect on purchase intention}

The coef fi cient of brand equity variable path to purchase intention of Philips light bulb in Batam City is 0, 289 with critical ratio value (CR) 5,556 and probability value equal to 0.000 . The probability value is less than 0.05 , this indicates the effect of the Philips bulb brand equity variable on the purchase intentions of Philips light bulb customers in Batam City is significant or reliable.

\section{References}

Azwar, S. (2013). Preparation of Psychological Scale (3rd ed.). Yogyakarta: Student Literature.

Besterfield, D. H. (1995). Total Quality Management. New Jersey: Prentice Hall.

Brady, Cronin, \& Brand. (2002). Performance-only means of service guality: A replication and extension. Journal of Business Research, 17-31. https://doi.org/10.1016/S0148-2963(00)00171-5

Buttle, \& Francis. (2007). Customer Relationship Management: Concepts and Technology. Oxford: Butterworth-Heinemann, imprint of Elsevier.

Ferdinand, \& Augusty. (2012). Structural Equation Modeling (SEM) In Management Research. Faculty of Economics Diponogoro University, Semarang.

Gropper, I. E., \& Boily, C. A. (1999). Breathing Life Into Customer Satisfaction. Nursing Management, November, 1-5. https://doi.org/10.1097/00006247-199911000-00024

Hair, J. F. et al. (2010). Multivariate data analysis (7th ed.). New Jersey: Pearson Education Inc.

Irawan, A., \& Pane, A. (2011). The Influence of Market Segmentation to Buy Interest in Citra Garden Housing Bandar Lampung. Scientific Journal of Echoes, 1(2), 66-79. 
Kalakota, R., \& Robinson, M. (2001). E-Business 2.0 Roadmap For Success. Addison - Wesley, USA.

Kotler, \& Keller. (2009). Marketing Management (13th ed.). Erland. Jakarta.

Kotler, P., \& Gary, A. (2012). Principles of Marketing (9th ed.). Prentice Hall, Inc., USA.

Mithas, S., Krishnan, M. S., \& Fornell, C. (2005). Why Do Customer Relationship Management Applications Affect Customer Satisfaction? Journal of Marketing, 69(4), 201-209. https://doi.org/10.1509/jmkg.2005.69.4.201

Parasuraman, A., Zeithaml, V. A., \& Berry, L. L. (1997). Reflections on Gaining Competitive Advantage Through Customer Value. Journal of the Academy of Marketing Science, 25(2), 154-161. https://doi.org/10.1007/BF02894351

Sheth, J. N., \& Atul, P. (2011). Handbook of Relationship Marketing. London: Sage Publications, Inc.

Singarimbun, M., \& Effendi, S. (2014). Survey Research Methods. LP3ES, Revised Edition, 2014.

Tjahyadi, R. A. (2012). Brand Trust In the Context of Brand Loyalty: The Role of Brand Characteristics, Corporate Characteristics, and Characteristics of Customer-Brand Relationships. Journal of Manajermen, $6(1)$.

Tjiptono, \& Fandy. (2015). Marketing Strategy. Keliam Edition, Andi. Yogyakarta.

\section{Copyrights}

Copyright for this article is retained by the author(s), with first publication rights granted to the journal.

This is an open-access article distributed under the terms and conditions of the Creative Commons Attribution license (http://creativecommons.org/licenses/by/4.0/). 